\title{
Measurement-based modelling of bromine-induced oxidation of mercury above the Dead Sea
}

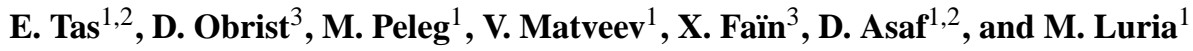 \\ ${ }^{1}$ The Institute of Earth Sciences, The Hebrew University, Jerusalem, Israel \\ ${ }^{2}$ Department of Environmental Sciences and Energy, The Weizmann Institute of Science, Rehovot, Israel \\ ${ }^{3}$ Division of Atmospheric Sciences, Desert Research Institute, 2215 Raggio Parkway, Reno, Nevada, 89512, USA \\ Correspondence to: E. Tas (eran.tas@weizmann.ac.il)
}

Received: 13 June 2011 - Published in Atmos. Chem. Phys. Discuss.: 31 August 2011

Revised: 7 February 2012 - Accepted: 19 February 2012 - Published: 5 March 2012

\begin{abstract}
Atmospheric mercury depletion events (AMDEs) outside the polar region - driven by high levels of gaseous $\mathrm{Br}$ and $\mathrm{BrO}$ (i.e., $\mathrm{BrO}_{\mathrm{x}}$ ) - were observed recently in the warm Dead Sea boundary layer. The efficient oxidation of gaseous elemental mercury (GEM) under temperate conditions by $\mathrm{BrO}_{\mathrm{x}}$ was unexpected considering that the thermal back dissociation reaction of $\mathrm{HgBr}$ is about 2.5 orders of magnitude higher under Dead Sea temperatures compared to polar temperatures, and hence was expected to significantly slow down GEM oxidation under warm temperatures. The goal of this modelling study was to improve understanding of the interaction of reactive bromine and mercury during Dead Sea AMDEs using numerical simulations based on a comprehensive measurement campaign in summer 2009.
\end{abstract}

Our analysis is focused on daytime AMDE when chemical processes dominate concentration changes. Best agreements between simulations and observations were achieved using rate constants for $k_{\mathrm{Hg}+\mathrm{Br}}$ and $k_{\mathrm{Hg}+\mathrm{BrO}}$ of $2.7 \times 10^{-13} \mathrm{~cm}^{3}$ molecule $^{-1} \mathrm{~s}^{-1}$ and $1.5 \times 10^{-13} \mathrm{~cm}^{3}$ molecule ${ }^{-1} \mathrm{~s}^{-1}$, respectively. Our model also predicted that a rate constant $k_{\mathrm{Hg}+\mathrm{BrO}}$ of $5.0 \times 10^{-14} \mathrm{~cm}^{3}$ molecule $\mathrm{e}^{-1} \mathrm{~s}^{-1}$ may be considered as a minimum, which is higher than most reported values. These rate constants suggest that $\mathrm{BrO}$ could be a more efficient oxidant than $\mathrm{Br}$ in the troposphere as long as $[\mathrm{Br}] /[\mathrm{BrO}]$ ratios are smaller than $\sim 0.2$ to 0.5. Under Dead Sea conditions, these kinetics demonstrate a high efficiency and central role of $\mathrm{BrO}_{\mathrm{x}}$ for AMDEs, with relative contributions to GEM depletion of more than $\sim 90 \%$. Unexpectedly, $\mathrm{BrO}$ was found to be the dominant oxidant with relative contributions above $80 \%$. The strong contribution of $\mathrm{BrO}$ could explain why the efficiency of GEM oxidation at the Dead Sea does not critically depend on $\mathrm{Br}$ and, therefore, is comparable to that in cold polar regions. In order to confirm the suggested kinetics, additional studies, particularly for temperature-dependence of rate constants, are required.

\section{Introduction}

Atmospheric mercury is a persistent and toxic global pollutant, and the major contributions of mercury loadings in remote locations are due to atmospheric deposition ( $\mathrm{Lu}$ et al., 2001; Driscoll et al., 2007). Most atmospheric mercury occurs as gaseous elemental mercury (GEM; $>95 \%)$ - a form which is relatively inert, has a low deposition velocity, and shows global lifetime of $\sim 1 \mathrm{yr}$ (Lindberg et al., 2007). Field measurements in polar regions showed that GEM can be oxidized rapidly to reactive forms (reactive gaseous mercury: RGM and particulate $\mathrm{Hg}: \mathrm{Hg}_{\mathrm{P}}$ ) after polar sunrise, followed by rapid deposition to the surface. Schroeder et al. (1998) were the first to show that during such events, termed Atmospheric Mercury Depletion Events (AMDEs), nearly complete depletion of GEM can occur within $24 \mathrm{~h}$ or less. There is a growing body of observational evidence indicating that rapid AMDEs, and subsequent scavenging by aerosols and deposition to the surface, are widespread in polar regions and the marine sub-Arctic and Antarctic (Lindberg et al., 2002; Ebinghaus et al., 2002; Berg et al., 2003; Skov et al., 2004; Poissant and Pilote, 2003; Steffen et al., 2008; Kim et al., 2010; Mao et al., 2010). The oxidation of GEM during AMDEs is considered to be caused by $\mathrm{Br}$ and $\mathrm{BrO}$ (i.e., 
$\mathrm{BrO}_{\mathrm{x}}=\mathrm{BrO}+\mathrm{Br}$ ) as well as other reactive halogen species (RHS) (Lu et al., 2001; Lindberg et al., 2001; Ariya et al., 2004; Brooks et al., 2006). As a result, AMDEs generally correlate with ozone depletion events (ODEs) (Bottenheim et al., 1986). It is well known that reactive halogens also can exist outside of polar regions at temperate, mid-latitude locations such as over salt lakes and in the marine boundary layer (MBL) (Hebestreit et al., 1999; Saiz-lopez et al., 2004). Due to the important role that $\mathrm{BrO}_{\mathrm{x}}$ plays in GEM oxidation, several studies, including modelling, focused on interactions of $\mathrm{BrO}_{\mathrm{x}}$ with atmospheric mercury in the polar region (Calvert and Lindberg, 2003; Skov et al., 2004; Hedgecock et al., 2008; Xie et al., 2008; Durnford et al., 2011; Subir et al., 2011; Stephens et al., 2012), in the MBL at mid-latitudes (Hedgecock and Pirrone, 2001, 2004; Hedgecock et al., 2003, 2005, 2008; Holmes et al., 2006, 2009), and in urban areas (Shon et al., 2005). Holmes et al. (2006) calculated a global chemical lifetime of atmospheric mercury of $0.5-1.7 \mathrm{yr}$ against oxidation by $\mathrm{Br}$, implying that $\mathrm{Br}$ is a significant oxidant of GEM on a global scale, and Holmes et al. (2009) found that oxidation of GEM by $\mathrm{Br}$ accounts for $35-60 \%$ of the MBL RGM source.

There are still significant uncertainties in regard to the reaction of $\mathrm{BrO}_{\mathrm{x}}$ with $\mathrm{Hg}$ (see Ariya et al., 2008; Calvert and Lindberg, 2004; and Xie et al., 2008). Reaction rates of $\mathrm{Br}$ and $\mathrm{BrO}$ with GEM are not well defined; it is not clear which is the dominant oxidant; and chemical pathways and products of RGM formation are unclear. Additional uncertainties exist regarding the role of other halogens such as I and IO (Raofie et al., 2008), $\mathrm{ClO}_{\mathrm{x}}$ (Stephens et al., 2012), $\mathrm{O}_{3}$ and $\mathrm{OH}$ (Xie et al., 2008 and references within), and temperaturedependence of rate constants (Ariya et al. 2008; Xie et al., 2008).

Recently, it was observed that strong AMDEs are not limited to the polar region but also occur in the mid-latitudes under temperate conditions: near-complete (up to $\sim 90 \%$ ) conversion of GEM to RGM was observed in the Dead Sea atmosphere under temperatures of $40^{\circ} \mathrm{C}$ and over (Peleg et al., 2007; Obrist et al., 2011). These pronounced Dead Sea AMDEs, which strongly correlated with high $\mathrm{BrO}_{\mathrm{x}}$, were unexpected given that the dissociation of $\mathrm{HgBr}$ (formed by GEM oxidation by $\mathrm{Br}$ ), a rate limiting step in GEM oxidation by $\mathrm{Br}$, is considered strongly temperature dependent (Goodsite, 2004).

The objective of our study was to improve understanding of the $\mathrm{BrO}_{\mathrm{x}}-\mathrm{Hg}$ interaction at the Dead Sea by combining results from a comprehensive measurement campaign with detailed modelling analysis. Due to the elevated $\left[\mathrm{Br}^{-}\right]$and $\left[\mathrm{Br}^{-}\right] /\left[\mathrm{Cl}^{-}\right]$ratio of the seawater (Niemi et al., 1997), low $\mathrm{pH}(<6$; Tas et al., 2005), and moderate anthropogenic pollution (Tas et al., 2005), extremely high levels of $\mathrm{BrO}_{\mathrm{x}}$ are formed almost daily at the Dead Sea (e.g., Tas et al., 2006). Due to regularly high $\mathrm{BrO}_{\mathrm{x}}$ levels, the Dead Sea provides excellent conditions for studying the interaction of $\mathrm{BrO}_{\mathrm{x}}$ with atmospheric mercury at mid-latitudes. We used the MECCA box model (Sander et al., 2005) heterogeneous mechanism, focusing on identifying reaction rates of $\mathrm{BrO}$ and $\mathrm{Br}$ with GEM, the relative importance of $\mathrm{BrO}_{\mathrm{x}}$ and other oxidants, and oxidation sensitivity to temperature.

\section{Experimental}

\subsection{Field measurements}

Model simulations are based on a comprehensive measurement campaign that took place at Ein Bokek, Israel (latitude $31.20^{\circ} \mathrm{N}$, longitude $35.37^{\circ} \mathrm{E}$ ) on the shore of the Dead Sea, between 29 June and 28 July 2009. Measurements are described in detail in Obrist et al. (2011), and additional details on methodology are found in Matveev et al. (2001) and Tas et al. (2005). In summary, measurements included speciated atmospheric mercury (GEM, RGM, and $\mathrm{Hg}_{\mathrm{P}}$ ) using Tekran Model 2537, Model 1130, and Model 1135 analyzers (Tekran Inc.; Toronto, Canada), $\mathrm{O}_{3}$ (TEII, Model 49C), NO-NO $\mathrm{N}_{\mathrm{x}}$ (TEII, Model 42i), $\mathrm{SO}_{2}$ (TEII, Model 43C), CO (TEII, Model 48i), and particulate sulfates (TEII, Model 5020i, all Thermo Environment Instrument Incorporated, Waltham, MA, USA). Meteorological conditions including wind speed and direction, temperature, relative humidity $(\mathrm{RH})$, barometric pressure, and solar radiation were measured using meteorological instruments (Met-One Instruments Inc. Grants Pass, Oregon, USA). Long-path differential optical absorption spectroscopy (LP-DOAS) technique (Model HMT DOAS Measuring System; Hoffmann Messtechnik, Rauensberg, Germany) was used to quantify $\mathrm{BrO}$ (detection limit as low as $3 \mathrm{pmol} \mathrm{mol}^{-1}$ ), $\mathrm{O}_{3}$ (detection limit generally $<7.3 \mathrm{nmol} \mathrm{mol}^{-1}$ ), and $\mathrm{NO}_{2}$ (detection limit generally $<0.5 \mathrm{nmol} \mathrm{mol}^{-1}$ ). The LP-DOAS system was placed in the top floor of an air-conditioned hotel room (18 $\mathrm{m}$ above water level and the same location as above instruments), and the DOAS reflector mirror was situated at the eastern side of an evaporation pond directly above the water surface, resulting in an $11.8 \mathrm{~km}$ light path traveling over the Dead Sea water. Details of the DOAS system and signal retrieval are described in Stutz and Platt (1996) and Peleg et al. (2007).

\subsection{Model description}

The model used in this analysis is the comprehensive heterogeneous MECCA box model (Sander et al., 2005). MECCA includes an explicit kinetic heterogeneous chemical mechanism, accounting for gas and aqueous phase reactions and heterogeneous reactions for two aerosol modes. In the gas phase, species are subjected to photochemical decomposition and dry deposition; aerosol processes include both scavenging and new particle formation. Gas-aerosol partitioning is performed based on Henry's law and kinetic limitations for coarse soluble and accumulation soluble aerosol modes. The $\mathrm{O}-\mathrm{H}-\mathrm{C}-\mathrm{N}-\mathrm{S}-\mathrm{Cl}-\mathrm{Br}-\mathrm{I}$ chemical mechanism includes 186 gas 
Table 1. Photochemical and meteorological ambient conditions. Several measured chemical and meteorological average (avr.), maximal (max.) and minimal (min.) values that were obtained during daytime (06:00-20:00 LT) are presented for Julian days 188 and 201.

\begin{tabular}{lll}
\hline Parameter & Julian day 188 (avr./max./min.) & Julian day 201 (avr./max./min.) \\
\hline $\mathrm{NO}_{2}\left(\mathrm{nmol} \mathrm{mol}^{-1}\right)$ & $1.2 / 4.2 / 0.1$ & $1.8 / 6.7 / 0.3$ \\
$\mathrm{O}_{3}\left(\mathrm{nmol} \mathrm{mol}^{-1}\right)$ & $37.2 / 69.4 /<7.5^{*}$ & $50.9 / 61.0 / 33.0$ \\
Wind speed $\left(\mathrm{m} \mathrm{s}^{-1}\right)$ & $2.3 / 12.0 / 0.7$ & $4.9 / 10.9 / 0.9$ \\
Relative humidity (\%) & $31.8 / 42.1 / 29.1$ & $28.7 / 39.4 / 25.2$ \\
Temperature (K) & $310.9 / 313.1 / 302.7$ & $313.5 / 316.2 / 304.8$ \\
Pressure (pascal) & $104924 / 105058 / 104658$ & $104764 / 105058 / 104525$ \\
\hline
\end{tabular}

$* \mathrm{O}_{3}$ concentrations dropped below the instrument detection limit which was equal or lower than $7.5 \mathrm{nmol} \mathrm{mol}^{-1}$.

phase reactions capturing 58 photolysis reactions, 266 aqueous reactions, and 154 heterogeneous reactions based on the default MECCA mechanism (http://www.mpch-mainz.mpg. $\mathrm{de} / \sim$ sander/messy/mecca/). The mercury chemical mechanism was added to the model for gas phase (Supplement Table S1), aqueous (Supplement Table S2), aqueous equilibrium (Supplement Table S3), and heterogeneous reactions (Supplement Table S4) involving sea salt and sulphate aerosols. Photolysis rate coefficients are calculated using the method described in Landgraf and Crutzen (1998) and were updated at each time step (1 min) representing real time and location of the measurement site.

The initial sea salt aerosol composition was based on the Dead Sea water composition accounting for $\mathrm{Br}^{-}$and $\mathrm{Cl}^{-}$ concentrations, as reported by Tas et al. (2005). In MECCA, the averaged mass transfer coefficient for each aerosol mode is based on integration over a lognormal shape distribution of the particle radius for each aerosol mode (Kerkweg et al., 2007). Dependence of average sea salt aerosol number concentrations on in situ measured wind speeds was taken into account using Eq. 4 in Gong et al. (1997) on five-minute time resolution. Average sulphate aerosol number concentrations were determined based on in situ measurements (Sect. 2.1) using reported densities (Karg et al., 1995) and radius dependency on RH (Yue, 1979) and were updated in the model on time resolution of $5 \mathrm{~min}$.

\subsection{Model simulations}

Initial model runs showed that reactive bromine production via aerosols is limited to RH higher than $28 \%$. Therefore, aerosol chemistry in our simulations was activated only for RH above $28 \%$. Smoydzin and von Glasow (2009) found that due to low $\mathrm{pH}$, direct release from the seawater is likely an additional source for $\mathrm{BrO}_{\mathrm{x}}$ at the Dead Sea. A $\mathrm{BrO}_{\mathrm{x}}$ source representing direct $\mathrm{Br}_{2}$ release from the seawater via the bromine explosion mechanism (Vogt et al., 1996) was parameterized in the model with a first order rate constant of $1.0 \times 10^{-3} \mathrm{~s}^{-1}$, as described in Obrist et al. (2011).

Simulation days showed dominant daytime local wind direction from the east and south (i.e., directly from the Dead
Sea) so that no significant sources from land were expected during mid-day AMDEs where we focused our investigation; however, during nighttime, morning, and evening advection and possibly other sources occur as explained below. Simulations were updated on a 5-min. time resolution using the following real-time measured parameters: temperature, $\mathrm{RH}$, wind speeds, and mixing ratios for $\mathrm{NO}, \mathrm{NO}_{2}, \mathrm{SO}_{2}$, and 13 different hydrocarbon species (based on $\mathrm{HC}$ measurements; see Tas et al., 2006). Table 1 presents typical measured values of chemical and meteorological parameters used during our simulations. Boundary layer height was determined using a 1-D meteorological model (McNider and Pielke, 1981) and was continuously updated. Photolysis rate coefficients were calculated by the MECCA model, representing clear sky conditions for the Dead Sea. Using the above in the model enabled to obtain relatively good agreements with measurements for $\mathrm{O}_{3}$ and $\mathrm{BrO}$ diurnal profiles (Sect. 3.1).

Our analysis is focused on daytime-AMDEs, during which GEM concentrations are mainly controlled by chemical processes, rather than other source or sink processes (such as advection or emission) which could not be well described by the used box model. Our measurements indicate that once AMDE/ODEs are terminated, both GEM and $\mathrm{O}_{3}$ are quickly advected back as indicated by sharp decrease in $\mathrm{BrO}$ and sharp rebounds of $\mathrm{O}_{3}$ and GEM to background levels. To account for this, $\mathrm{O}_{3}$ and GEM fluxes were added for $30 \mathrm{~min}$ at the end of AMDE/ODEs to simulate these rebounds. For Julian day (JD) 197, GEM fluxes were added instead between 07:30-08:00, and during $\mathrm{JD}=188$ fluxes were also added between 07:30 and 13:30 (see Sect. 3.2). It is important to note that no fluxes were added during the simulation of AMDEs which is the main focus of our study. Hence, our model simulations focused on the chemical and kinetic processes during AMDEs, as opposed to processes such as advection, surface emissions, or pollution inputs - all of which affect $\mathrm{Hg}$ and $\mathrm{O}_{3}$ concentrations during non-AMDEs periods.

Simulations were performed for three measurement days (Julian days 188, 197, and 201) using different combinations of reaction rates for $\mathrm{Hg}$ with $\mathrm{Br}$ and $\mathrm{BrO}$ (see 
Table 2. Key to different simulation types. Simulations 1-4 were performed for four different days from the measurement campaign (Julian days 188, 197 and 201) using different combinations for the rate of $\mathrm{Hg}$ with $\mathrm{Br}$ and $\mathrm{BrO}$ : low and high $k_{\mathrm{Hg}+\mathrm{Br}}\left(=2.7 \times 10^{-13}\right.$ and $1.1 \times 10^{-12} \times(T / 298)^{-2.37} \mathrm{~cm}^{3}$ molecule $\left.{ }^{-1} \mathrm{~s}^{-1}\right)$ for "L_Br" and "H_Br", respectively, based on Donohoue et al. (2006) and Goodsite et al. (2004); $k_{\mathrm{Hg}+\mathrm{BrO}}=1 \times 10^{-15}$ and $5 \times 10^{-14} \mathrm{~cm}^{3}$ molecule $\mathrm{s}^{-1}$ for "L_BrO" and "M_BrO," respectively, based on Raofie and Ariya (2003); and $k_{\mathrm{Hg}+\mathrm{BrO}}=1.5 \times 10^{-13} \mathrm{~cm}^{3}$ molecule ${ }^{-1} \mathrm{~s}^{-1}$ for "H_BrO". "L_Br_H_BrO", is referred to as "BASE" simulation due to best agreement with measurements. Simulations 5-10 were performed for Julian days 188 and 201 which represent typical days of relatively high Dead Sea BrO levels (see additional details in Sect. 3.1).

\begin{tabular}{|c|c|c|}
\hline Number & Simulation & Individual conditions for calculations \\
\hline 1 & L_Br_H_BrO/BASE & Low $k_{\mathrm{Hg}+\mathrm{Br}}$ and high $k_{\mathrm{Hg}+\mathrm{BrO}}$ \\
\hline 2 & L_Br_M_BrO & Low $k_{\mathrm{Hg}+\mathrm{Br}}$ and medium $k_{\mathrm{Hg}+\mathrm{BrO}}$ \\
\hline 3 & $\mathrm{~L} \_\mathrm{Br} \_\mathrm{L} \_\mathrm{BrO}$ & Low $k_{\mathrm{Hg}+\mathrm{Br}}$ and $k_{\mathrm{Hg}+\mathrm{BrO}}$ \\
\hline 4 & $\mathrm{H} \_\mathrm{Br} \_\mathrm{L} \_\mathrm{BrO}$ & High $k_{\mathrm{Hg}+\mathrm{Br}}$ and low $k_{\mathrm{Hg}+\mathrm{BrO}}$ \\
\hline 5 & NOBROX & Similar to BASE, not including $\mathrm{BrO}_{\mathrm{x}}$ as GEM oxidants \\
\hline 6 & ONLYBROX & Similar to BASE, including only $\mathrm{BrO}_{\mathrm{x}}$ as GEM oxidants \\
\hline 7 & ONLYBR & Similar to BASE, including only $\mathrm{Br}$ as GEM oxidants \\
\hline 8 & WINTER & $\begin{array}{l}\text { Similar to BASE, with GEM chemistry based on winter } \\
\text { Dead Sea temperatures (averaged at } \sim 294 \mathrm{~K} \text { ) }\end{array}$ \\
\hline 9 & POLAR & $\begin{array}{l}\text { Similar to BASE, with GEM chemistry based on polar } \\
\text { regions temperatures (averaged at } 240 \mathrm{~K} \text { ) }\end{array}$ \\
\hline
\end{tabular}

Table 2). Based on a literature review and sensitivity analysis (Sect. 3.2), simulations were based on low and high values for $k_{\mathrm{Hg}+\mathrm{Br}}$, with values of $2.7 \times 10^{-13} \mathrm{~cm}^{3}$ molecule ${ }^{-1} \mathrm{~s}^{-1}$ and $1.1 \times 10^{-12} \times(T / 298)^{-2.37} \mathrm{~cm}^{3}$ molecule ${ }^{-1} \mathrm{~s}^{-1}$ (termed "L_Br" and "H_Br", respectively). For $k_{\mathrm{Hg}+\mathrm{BrO}}$, we used values of $1 \times 10^{-15}$ and $5 \times 10^{-14} \mathrm{~cm}^{3}$ molecule $^{-1} \mathrm{~s}^{-1}$ (termed "L_BrO" and "M_BrO") plus a value of $1.5 \times 10^{-13} \mathrm{~cm}^{3}$ molecule ${ }^{-1} \mathrm{~s}^{-1}$ (termed "H_BrO"). "L_Br_H_BrO" led to best agreement with measurements and is termed "BASE" simulation, although it uses $k_{\mathrm{Hg}+\mathrm{BrO}}$ which is higher than the upper limit of previously reported theoretical and laboratory studies.

Additional detailed simulations were performed for Julian days 188 and 201 (Table 2). Simulation "NOBROX" is identical to the "BASE" simulation, except that all direct reactions of $\mathrm{Hg}$ with $\mathrm{BrO}_{\mathrm{x}}$ were switched off. Simulations "ONLYBROX" and "ONLYBR" are identical to the "BASE" simulation except that they include only $\mathrm{BrO}_{\mathrm{x}}$ and $\mathrm{Br}$ as GEM oxidants, respectively. All above simulations used real-time in situ measured summer Dead Sea temperatures (which averaged $\sim 310 \mathrm{~K}$ during the summer). In addition, "WINTER" and "POLAR" simulations are identical to the "BASE" simulation, except that typical winter Dead Sea temperatures $(294 \mathrm{~K})$ and polar temperatures $(240 \mathrm{~K})$ were used instead of real-time summer temperatures.

\section{Results and discussion}

\subsection{Model verification}

The primary, non-halogen, gas-phase oxidants of GEM considered in the urban and lower troposphere boundary layer are $\mathrm{O}_{3}, \mathrm{H}_{2} \mathrm{O}_{2}$, and $\mathrm{OH}$ (Hedgecock et al., 2005; Holmes et al., 2009; Sillman et al., 2007; Spivakovsky et al., 2000). In the marine boundary layer and upper troposphere, halogens are presumed to be the dominant oxidants (Lin et al., 2006). Atomic bromine is a major global sink for GEM, especially in the middle and upper troposphere where relatively cold temperatures suppress thermal back-decomposition of the $\mathrm{HgBr}$ intermediate (Holmes et al., 2006; Lin et al., 2006). During AMDEs in the polar regions, RHS, particularly $\mathrm{BrO}_{\mathrm{x}}$, dominate the rate of GEM depletion (e.g., Xie et al., 2008). At the Dead Sea, AMDEs are strongly linked to $\mathrm{BrO}_{\mathrm{x}}$ levels as well (Obrist et al., 2011), primarily due to the very high concentrations of reactive bromine species compared to reactive chlorine species which are not expected to play a significant role at the Dead Sea (Tas et al., 2006). In addition, iodine concentrations are generally low when bromine species are active (Zingler and Platt, 2005). Still, our model was configured to include a detailed account of multiphase chemical reactions involving all halogens (reactive bromine, chlorine, and iodine; based on the actual Dead Sea water composition Sect. 2.2) plus non-halogen oxidants.

Figure 1 shows good agreements between simulated and measured $\mathrm{O}_{3}$ concentrations during AMDEs for JD $=188$ and 201, the two main days used for analysis. Model evaluation also showed good agreement of $\mathrm{BrO}$ concentrations (Figs. 2, 3 and Supplement Fig. S1), particularly during the occurrence of mid-day AMDEs. We focused further detailed analyses on comparing results for JDs 188 and 201 as they are characterized by inherently different $\mathrm{BrO}_{\mathrm{x}}$ levels and associated $[\mathrm{Br}] /[\mathrm{BrO}]$ ratios, with maximum $\mathrm{BrO}$ levels of $\sim 90 \mathrm{pmol} \mathrm{mol}^{-1}$ (JD 188) - as frequently observed over the Dead Sea - and levels of $\sim 30 \mathrm{pmol} \mathrm{mol}^{-1}$ (JD 201), as typically observed in the polar boundary layer. 


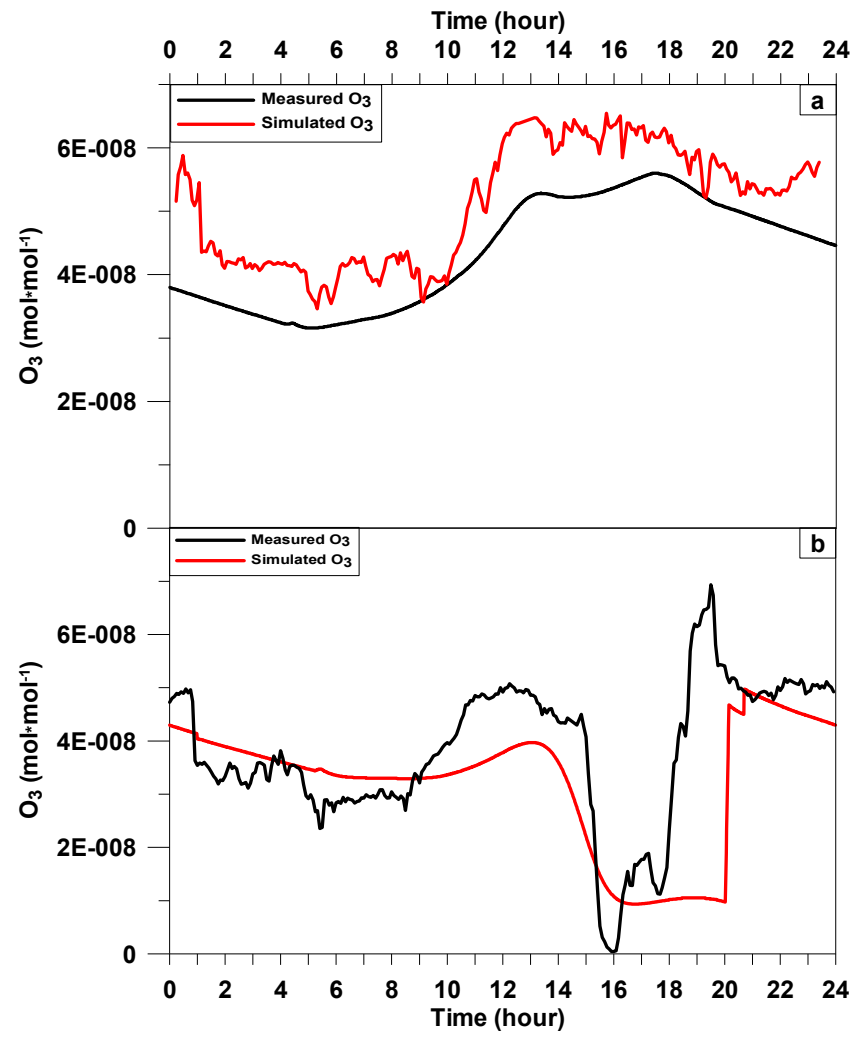

Fig. 1. Simulated and LP-DOAS measured $\mathrm{O}_{3}$ mixing ratios. Comparisons are shown for Julian days 201 (panel a) and 188 (panel b).

\subsection{Reaction rates of GEM with $\mathrm{Br}$ and $\mathrm{BrO}$}

We performed sensitivity analyses to calibrate the model with respect to reaction rates of $\mathrm{Br}$ and $\mathrm{BrO}$ with GEM (Figs. 2-4 and Supplement Fig. S1). Note that for JD $=188$, GEM depletions occurred too early and were too intense for most combinations of rate constants (Fig. 2b), except in one case ( $\mathrm{L} \_\mathrm{Br} \_$L_BrO) when GEM depletion could not be simulated to its full extent. We chose to constrain GEM concentrations between 07:30 and 13:30 LT (i.e., prior to the onset of the AMDE; Fig. 2c); the reason for the elevated measured GEM levels is unknown but is likely due to entrainment of GEM from other areas or from other sources that are not accounted in our chemical box model. Figure 4 shows scatter plots of measured GEM concentrations ( $\mathrm{x}$-axis) with correspondingly simulated concentrations ( $\mathrm{y}$-axis) during mid-day AMDEs for all combinations of reaction rates for the three days of simulations, and Table 3 shows corresponding summary statistics. GEM depletions were best reproduced when employing "BASE" ("LBr_HBrO") and L_Br_M_BrO simulations. Values of $k_{\mathrm{Hg}+\mathrm{BrO}}$ smaller than used in these two cases yielded fair agreement only for the day with high $\mathrm{BrO}$ levels and a high $[\mathrm{Br}] /[\mathrm{BrO}]$ ratio (i.e., JD 188), and strongly underestimated GEM depletion for the days with lower $\mathrm{BrO}$ levels (i.e., JD 197 and 201). Figure 4 emphasizes that the

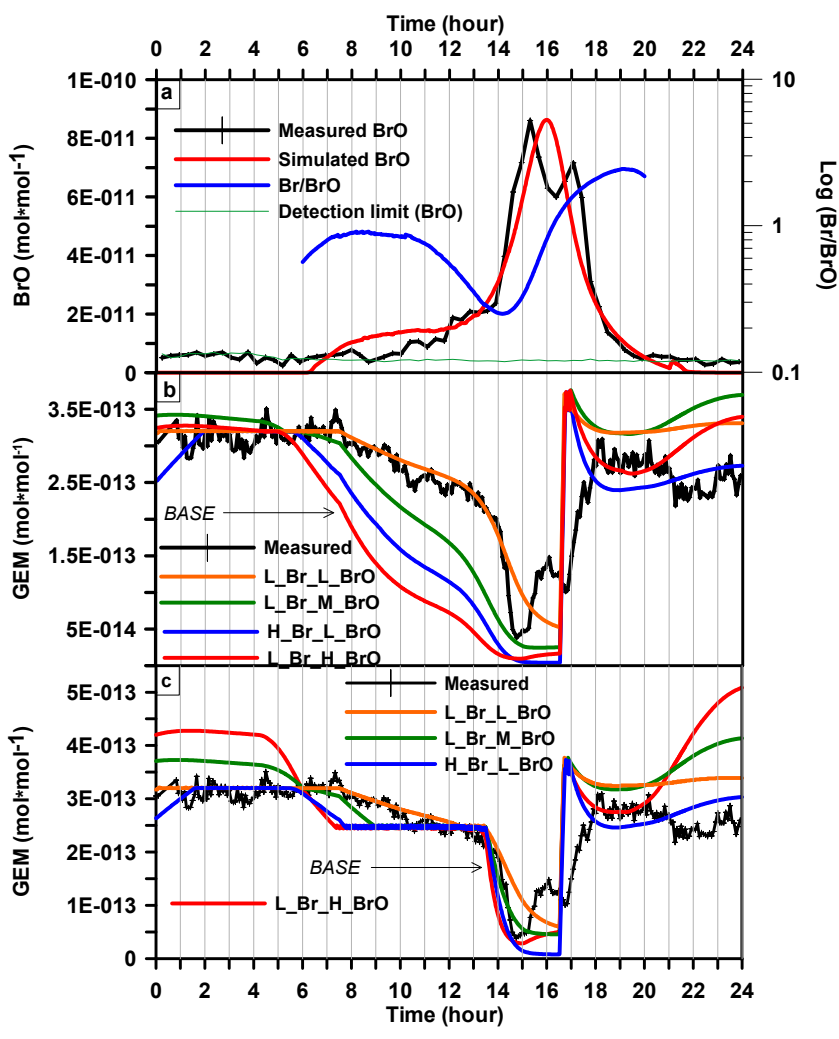

Fig. 2. Simulated and measured diurnal profiles of GEM and BrO. (a) Measured and simulated diurnal profiles of $\mathrm{BrO}$, and simulated diurnal profile of $[\mathrm{Br}] /[\mathrm{BrO}]$ for Julian day 188. (b) GEM diurnal profiles for different combinations of $k_{\mathrm{GEM}}+\mathrm{BrO}$ and $k_{\mathrm{GEM}+\mathrm{Br}}$ values. (c) Same as (b) with simulated GEM mixing ratios being constrained between 07:30 and 13:30 LT. Note that constrains of fluxes were not added during AMDEs which was the main emphasis of our analyses.

"BASE" simulation (i.e., L_Br_H_BrO) achieves best agreement under moderate $\mathrm{BrO}$ concentrations (i.e., $\mathrm{JD}=197$ and $201 ; \mathrm{BrO}<\sim 45 \mathrm{pmol} \mathrm{mol}^{-1}$ ), while L_Br_M_BrO appears to achieve better results on JD 188 with very high $\mathrm{BrO}_{\mathrm{x}}\left(\mathrm{BrO}>80 \mathrm{pmol} \mathrm{mol}^{-1}\right)$. High $\mathrm{BrO}$ levels on JD 188 cause correspondingly low $\mathrm{O}_{3}$ and high $[\mathrm{Br}] /[\mathrm{BrO}]$ ratios, while $[\mathrm{Br}] /[\mathrm{BrO}]$ ratios for JDs 197 and 201 are lower. On these days, using $k_{\mathrm{Hg}+\mathrm{BrO}}$ values smaller than $\mathrm{M} \mathrm{BrO}$ greatly underestimates GEM depletions. This suggests that $k_{\mathrm{Hg}+\mathrm{BrO}}$ should be at least as high as in $\mathrm{L} \_\mathrm{Br} \_\mathrm{M} \_\mathrm{BrO}$ (i.e., $5 \times 10^{-14} \mathrm{~cm}^{3}$ molecule $\mathrm{e}^{-1} \mathrm{~s}^{-1}$ ) and could be as high as in "BASE" simulation (i.e., $1.5 \times 10^{-13} \mathrm{~cm}^{3}$ molecule ${ }^{-1} \mathrm{~s}^{-1}$, see below).

We attribute overestimation of GEM depletion on JD 188 to under-estimation of simulated $\mathrm{O}_{3}$ during that AMDE (between $\sim 13: 30$ and 14:45 LT; Fig. 1) which would overpredict $[\mathrm{Br}] /[\mathrm{BrO}]$ ratios. Based on our analysis (see Fig. 5), $[\mathrm{Br}] /[\mathrm{BrO}]$ ratios on that day could have been overestimated by up to a factor of $\sim 2$, which would overestimate 


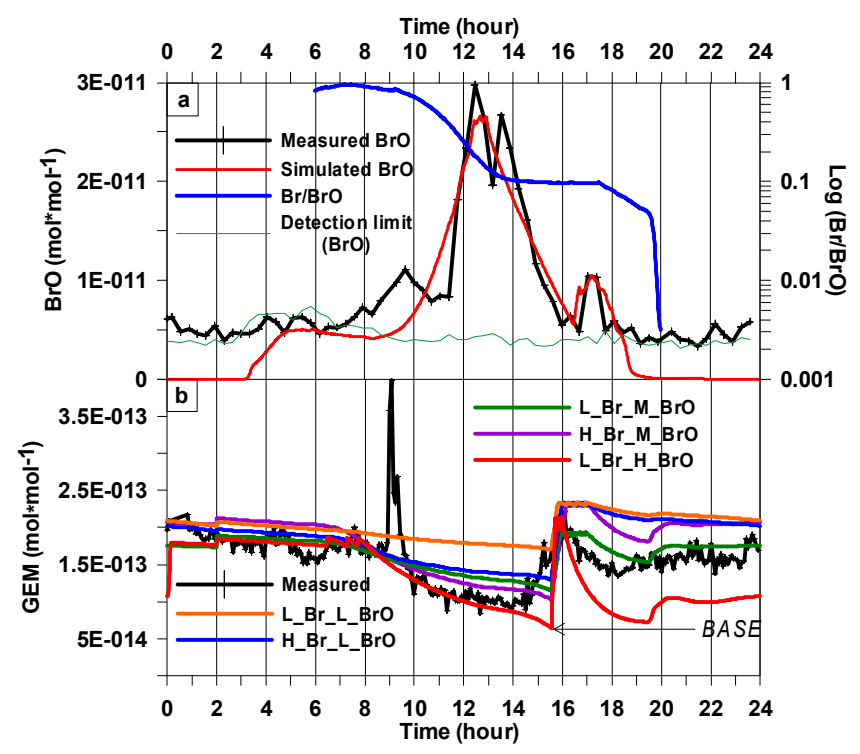

Fig. 3. Simulated and measured diurnal profiles of GEM and $\mathrm{BrO}$. (a) Measured and simulated diurnal profiles of $\mathrm{BrO}$ and simulated diurnal profile of $[\mathrm{Br}] /[\mathrm{BrO}]$ for Julian day 201. (b) Different combinations of values for $k_{\mathrm{GEM}+\mathrm{BrO}}$ and $k_{\mathrm{GEM}+\mathrm{Br}}$ were used to evaluate the simulated GEM diurnal profiles.

depletion of GEM by $\mathrm{Br}$ at the expense of BrO. The good fit of GEM depletion for the "BASE" simulation on days 197 and 201 - two days with quite different $[\mathrm{Br}] /[\mathrm{BrO}]$ ratios - suggest that the rate constants used by "BASE" fit observations quite well. We suggest that a value of $2.7 \times 10^{-13} \mathrm{~cm}^{3}$ molecule $\mathrm{s}^{-1}$ for $k_{\mathrm{Hg}+\mathrm{Br}}$ and a lower and upper limit of $5 \times 10^{-14} \mathrm{~cm}^{3}$ molecule $\mathrm{s}^{-1}$ and $1.5 \times$ $10^{-13} \mathrm{~cm}^{3}$ molecule ${ }^{-1} \mathrm{~s}^{-1}$ for $k_{\mathrm{GEM}+\mathrm{BrO}}$ seem reasonable rate coefficients to reproduce observed AMDEs at the Dead Sea. It should be emphasized that improved knowledge of kintetics, particularly temperature-dependence of rate constants (Ariya et al., 2008; Xie et al., 2008) are needed to confirm the above suggested rate constants.

Previous studies (Goodsite et al., 2004; Ariya et al., 2002; Calvert and Lindberg, 2004; Peleg et al., 2007) indicated that GEM oxidation by $\mathrm{Br}$ predominates over oxidation by $\mathrm{BrO}$, since theoretical kinetic calculations suggest that the reaction of $\mathrm{BrO}$ with $\mathrm{Hg}$ is endoergic and, therefore, unlikely to occur in the atmosphere (Tossell et al., 2003; Holmes et al., 2006; Shepler et al., 2007). Experimental studies, however, found conflicting data on the energetics of the species existing in the vapor over heated $\mathrm{HgO}_{(\mathrm{s})}$ (Tossell et al., 2006), suggesting that oxidation of GEM by $\mathrm{BrO}$ may be significant. Stephens et al. (2012) found that while $\mathrm{Br}$ had the greatest overall contributions to GEM depletion in the Arctic, $\mathrm{BrO}$ on some occasions nearly matched the importance of Br. Overall, a wide range of reaction rates have been published during the last decade, suggesting that GEM oxidation by $\mathrm{Br}$ ranges between a high value

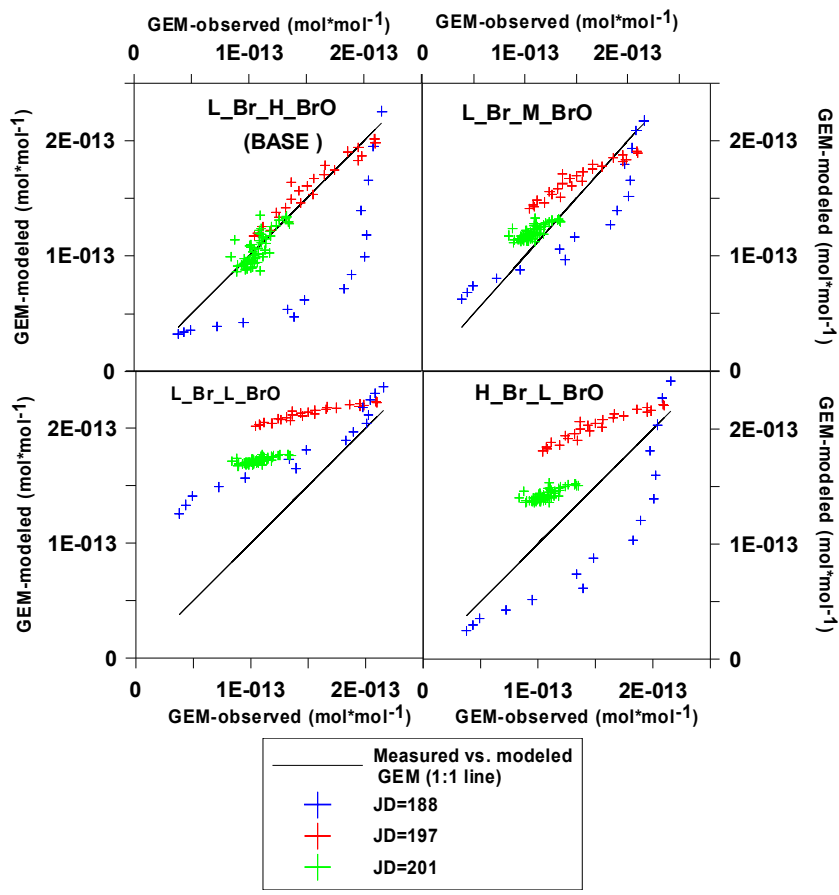

Fig. 4. Comparison between measured (x-axis) and simulated (y-axis) GEM mixing ratios during midday AMDEs.

Table 3. Correlation and average error during AMDEs as an indicator for simulated GEM agreement with measured GEM during AMDEs.

\begin{tabular}{lcccc}
\hline $\begin{array}{l}\text { Julian } \\
\text { day }\end{array}$ & $\begin{array}{c}\text { L_Br_H_BrO } \\
\text { (BASE) }\end{array}$ & L_Br_M_BrO & L_Br_L_BrO & H_Br_L_BrO \\
\hline 188 & $0.79 / 33.83$ & $0.80 / 46.86$ & $0.66 / 68.25$ & $0.80 / 55.40$ \\
197 & $0.90 / 25.27$ & $0.94 / 6.36$ & $0.85 / 53.60$ & $0.85 / 37.56$ \\
201 & $0.75 / 27.33$ & $0.76 / 8.52$ & $0.75 / 68.73$ & $0.76 / 34.30$ \\
\hline
\end{tabular}

of $1 \times 10^{-13}-3 \times 10^{-12} \mathrm{~cm}^{3}$ molecule ${ }^{-1} \mathrm{~s}^{-1}$ (see Ariya et al., 2008 and references within) and lower oxidation rates by $\mathrm{BrO}$ of $10^{-13}-10^{-15} \mathrm{~cm}^{3}$ molecule ${ }^{-1} \mathrm{~s}^{-1}$ (Raofie and Ariya, 2003; Spicer et al., 2002). Recently, Xie et al. (2008) showed that model simulations could best reproduce observed correlations between GEM and $\mathrm{O}_{3}$ for rate constants of GEM oxidation by $\mathrm{Br}$ and $\mathrm{BrO}$ on the magnitude of $3 \times 10^{-13}$ and $\leq 1.0 \times 10^{-15} \mathrm{~cm}^{3}$ molecule ${ }^{-1} \mathrm{~s}^{-1}$, respectively, which are different than values proposed in our study (see above). One reason for the discrepancy between theirs and our rate constants may be that they used correlations between GEM and $\mathrm{O}_{3}$ to assess GEM and $\mathrm{O}_{3}$ depletion rates by $\mathrm{BrO}_{\mathrm{x}}$. Correlations between $\mathrm{O}_{3}$ and GEM, however, are subject to absolute $\mathrm{O}_{3}$, GEM, and $\mathrm{BrO}_{\mathrm{x}}$ levels (e.g., Fig. 5). In our study, GEM depletion rates were not based on correlations to $\mathrm{O}_{3}$ but on ratios of $[\mathrm{Br}] /[\mathrm{BrO}]$ to assess relative influences of $\mathrm{BrO}$ and $\mathrm{Br}$ on GEM depletion rates. 


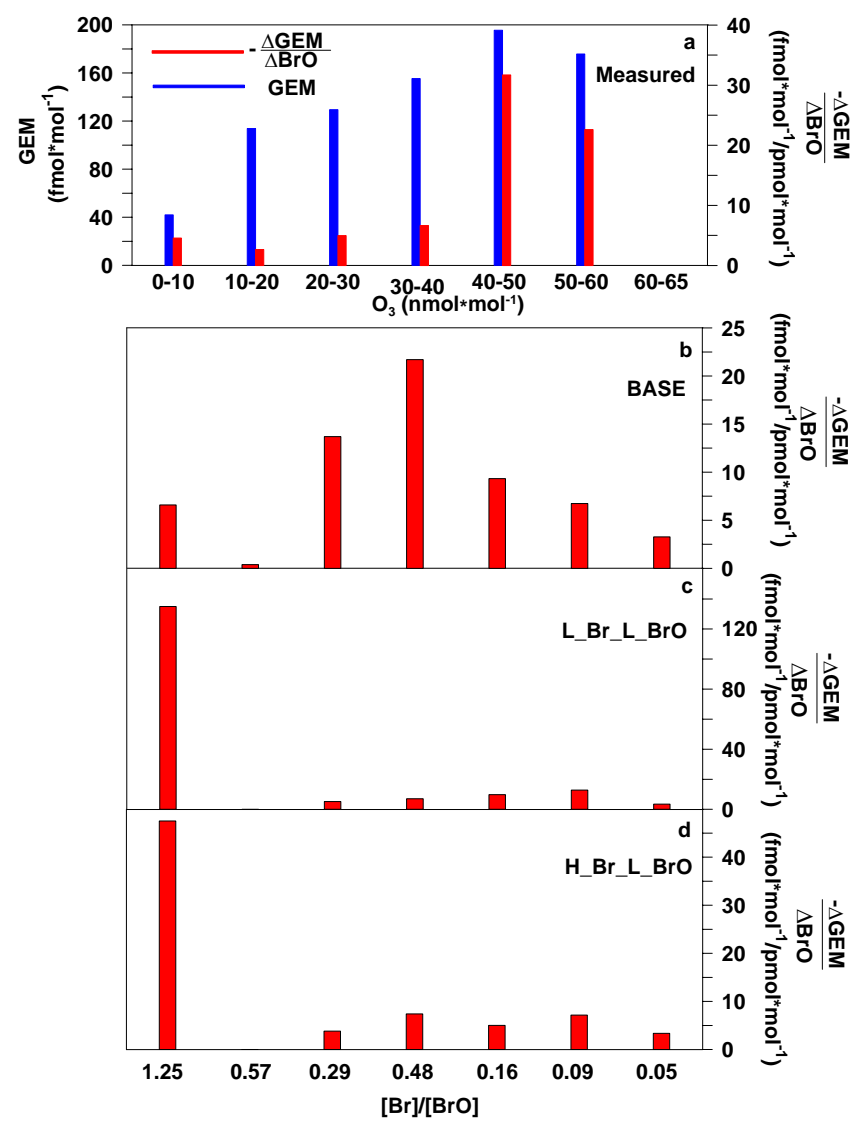

Fig. 5. Relative importance of $\mathrm{Br}$ and $\mathrm{BrO}$ to GEM-oxidation based on underlying LP-DOAS $\mathrm{O}_{3}$ mixing ratios. (a) Measured GEM depletion per unit $\mathrm{BrO}$ (i.e., $\Delta \mathrm{GEM} / \Delta \mathrm{BrO}$ ) is presented as a function of $\mathrm{O}_{3} . \Delta \mathrm{GEM} / \Delta \mathrm{BrO}$ was calculated for all campaign days and averaged for respective $\mathrm{O}_{3}$ values. (b-d) Simulated $\Delta \mathrm{GEM} / \Delta \mathrm{BrO}$ as a function of $[\mathrm{Br}] /[\mathrm{BrO}]$ for simulations $\mathrm{L} \_\mathrm{Br} \_\mathrm{H} \_\mathrm{BrO}$ (i.e.,

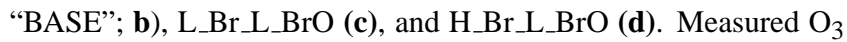
are expected to correspond to $[\mathrm{Br}] /[\mathrm{BrO}]$ ratios in simulations due to known correlations between the two. Simulated $\Delta \mathrm{GEM} / \Delta \mathrm{BrO}$ values were calculated only for periods of $\Delta \mathrm{BrO}>0$ based on Julian days 188, 197, and 201.

Figure 5a shows relationships between measured GEM, $\mathrm{BrO}$, and $\mathrm{O}_{3}$. We graphed GEM depletion per unit change in $\mathrm{BrO}$ (i.e., $\Delta \mathrm{GEM} / \Delta \mathrm{BrO}$ ) as a function of respective $\mathrm{O}_{3}$ concentrations, and only daytime values and data when $\Delta \mathrm{BrO}>0$ were used. Clearly, $\Delta \mathrm{GEM} / \Delta \mathrm{BrO}$ increases with higher $\mathrm{O}_{3}$ levels. Ratios of $[\mathrm{Br}] /[\mathrm{BrO}]$, however, are expected to anti-correlate with $\mathrm{O}_{3}$ (e.g., Wayne et al., 1995; Tas et al., 2008); therefore we expect that oxidation of GEM by $\mathrm{BrO}$ will increase at the expense of oxidation by $\mathrm{Br}$ for high $\mathrm{O}_{3}$ levels (Xie et al., 2008). Figure 5a implies that GEM oxidation by $\mathrm{BrO}$ predominates over oxidation by $\mathrm{Br}$, in agreement with model results in Fig. 6. We rule out that these patterns are caused by correspondingly different GEM concentrations (blue bars in Fig. 5a) as these did not well correlate with $\Delta \mathrm{GEM} / \Delta \mathrm{BrO}$.
Figure $5 \mathrm{~b}-\mathrm{d}$ shows simulated $\Delta \mathrm{GEM} / \Delta \mathrm{BrO}$ for Julian days 188,201 , and 197 . In these graphs, $\Delta \mathrm{GEM} / \Delta \mathrm{BrO}$ is graphed as a function of $[\mathrm{Br}] /[\mathrm{BrO}]$ (which is based on, and hence analogous to, $\mathrm{O}_{3}$ levels in panel a). Our results indicate that modeled $\Delta \mathrm{GEM} / \Delta \mathrm{BrO}$ versus $[\mathrm{Br}] /[\mathrm{BrO}]$ is similar to observed patterns only for the "BASE" simulation (Fig. 5b). Even for this case, however, $\Delta \mathrm{GEM} / \Delta \mathrm{BrO}$ ratios tend to peak at somewhat lower $\mathrm{O}_{3}$, which may suggest that the ratio of rate constants for $\mathrm{BrO}$ and $\mathrm{Br}$ (e.g., $\left.k_{\mathrm{GEM}+\mathrm{BrO}} / k_{\mathrm{GEM}+\mathrm{Br}}\right)$ still may be underestimated for the "BASE" simulation. For simulations "H_Br_L_BrO" and "L_Br_L_BrO", $\Delta \mathrm{GEM} / \Delta \mathrm{BrO}$ was greatly overestimated for $\mathrm{O}_{3}$ levels below $10 \mathrm{nmol} \mathrm{mol}^{-1}$, which is expected if $k_{\mathrm{GEM}+\mathrm{BrO}} / k_{\mathrm{GEM}+\mathrm{Br}}$ is underestimated. This result further suggests that the rate constant for $\mathrm{L} \_\mathrm{BrO}$ is too low to accurately represent observed results. Possibly, a decrease in efficiency of GEM depletion by $\mathrm{BrO}$ at $\mathrm{O}_{3}$ levels above $~ 30$ $40 \mathrm{nmol} \mathrm{mol}^{-1}$ as observed in the "BASE" simulation may be due to the importance of $\mathrm{O}_{3}$ for GEM oxidation at high $\mathrm{O}_{3}$ levels.

\subsection{Relative contributions of oxidants to GEM depletions}

Figure 6 shows relative contributions of various oxidants to GEM depletion rates and associated GEM lifetimes for Julian days 188 and 201 using the "BASE" simulation. This figure demonstrates that $\mathrm{BrO}_{\mathrm{x}}$ contributed more than $90 \%$ and $85 \%$, respectively, to GEM depletion on a 24-h basis. Most of the GEM oxidation ( $>80 \%$ ) was caused by BrO, especially under lower $\mathrm{BrO}_{\mathrm{x}}$ levels associated with higher $\mathrm{O}_{3}$ levels and hence low $[\mathrm{Br}] /[\mathrm{BrO}]$ ratios. The associated diurnal average GEM lifetime against oxidation by $\mathrm{BrO}$ for Julian day 188 is $41.2 \mathrm{~min}$, equivalent to a lifetime of $6.86 \mathrm{~min}$ for the daily peak $\mathrm{BrO}$ level of $90 \mathrm{pmol} \mathrm{mol}^{-1}$. Under lower $\mathrm{BrO}_{\mathrm{x}}$ concentrations, the relative contributions of $\mathrm{Br}$ and $\mathrm{Br}_{2}$ are comparable due to relatively lower $[\mathrm{Br}] /[\mathrm{BrO}]$ ratios. The integrated sum contribution of $\mathrm{NO}_{3}, \mathrm{O}_{3}$, and $\mathrm{OH}$ was between $\sim 4$ and $8 \%$ on a 24 -h basis for these simulation days.

The similarity in rate constants of the reactions of $\mathrm{Br}$ and BrO with GEM, using the rate constants of the "BASE" simulation, suggests that the role of $\mathrm{BrO}$ in GEM oxidation may dominate over $\mathrm{Br}$ as long as $[\mathrm{Br}] /[\mathrm{BrO}]$ remains below $\sim 0.2-$ 0.5 , which is expected for $\mathrm{O}_{3}>4-5 \mathrm{nmol} \mathrm{mol}^{-1}$ (Fig. 5). This is usually the case in the troposphere (e.g. Fig. 5; Wayne et al., 1995). It is important to note that contributions of $\mathrm{Br}$ and $\mathrm{BrO}$ to GEM oxidation, as well as suggested rate constants, are based on best fits of observations and model results during mid-day AMDEs under Dead Sea conditions; relative contributions of $\mathrm{Br}$ to GEM oxidation are expected to be higher in other areas, where lower temperatures are associated with lower back dissociation of $\mathrm{HgBr}$. 


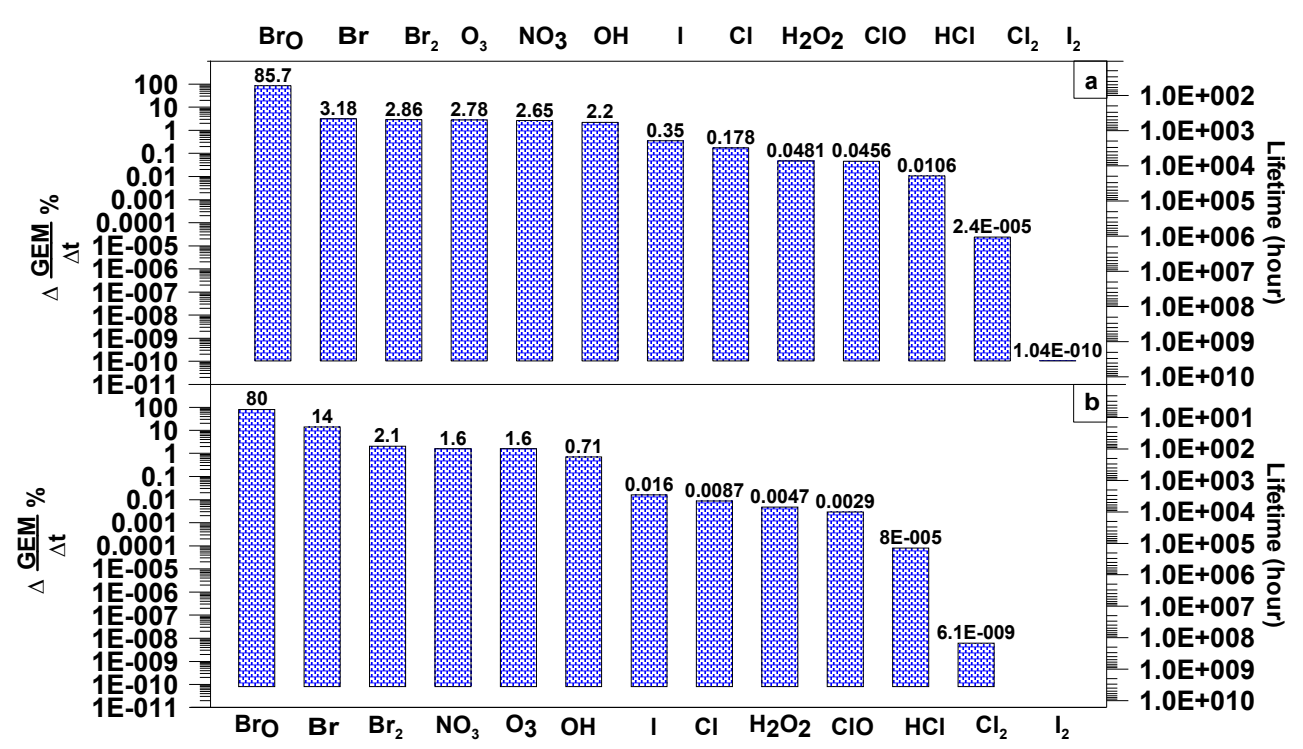

Fig. 6. Relative contributions of various oxidants to GEM depletion. Relative contributions (in \%) of different species to GEM oxidation and associated GEM lifetimes for Julian days 201 (a) and 188 (b), based on "BASE" simulation. Maximum mixing ratios of $20 \mathrm{pmol} \mathrm{mol}^{-1}$ were used for $\mathrm{NO}_{3}$.

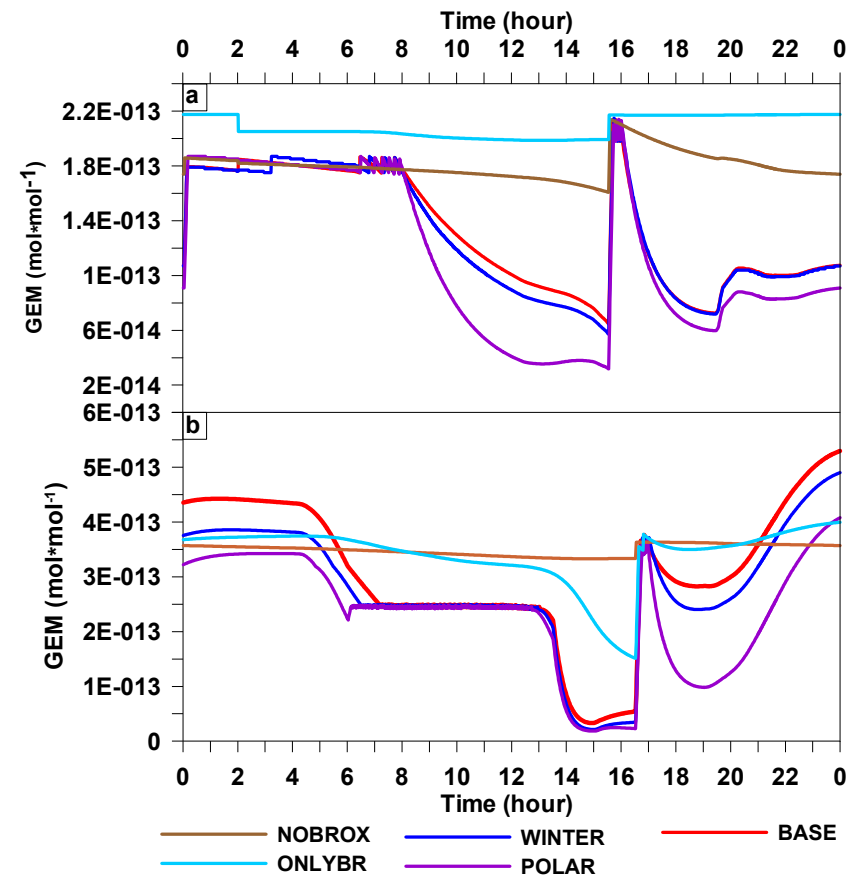

Fig. 7. Influence of $\mathrm{BrO}_{\mathrm{x}}$ and temperature on GEM depletion. The GEM diurnal profiles are shown for the "BASE", "WINTER", "POLAR", "NOBROX", and "ONLYBR" simulations for Julian days 188 (a) and 201 (b).

\subsection{Temperature effects}

Temperature can significantly influence the efficiency of GEM oxidation by $\mathrm{BrO}_{\mathrm{x}}$ in the gaseous and aqueous phases. Temperature-dependencies for many mercury reactions are unknown, but the thermal back-dissociation of $\mathrm{HgBr}$ is expected to significantly slow down GEM oxidation in the gas phase (Goodsite et al., 2004). Using the rate coefficient given by Goodsite et al. (2004) for the back dissociation rate of $\mathrm{HgBr}$, the thermal back-dissociation of $\mathrm{HgBr}$ is $\sim 2.6$ orders of magnitude higher under the average Dead Sea summer temperature measured during the campaign $(\sim 310 \mathrm{~K}) \mathrm{com}-$ pared to typical temperatures in the polar regions $(240 \mathrm{~K})$. Hence, if Br plays a major role in GEM oxidation one should expect significantly slower oxidation of GEM by $\mathrm{BrO}_{\mathrm{x}}$ at the Dead Sea compared with the polar regions.

Figure 7 presents the GEM diurnal profile obtained for "BASE", "WINTER", and "POLAR" simulations in order to investigate temperature effects on GEM oxidation. Only direct effects of temperature on the Hg-involved chemical reactions were investigated, while indirect effects of temperature - for instance, on the release of $\mathrm{BrO}_{\mathrm{x}}$ into the gas phase (Sander et al., 2006) - were ignored here. Figure $7 \mathrm{~b}$ demonstrates that under relatively moderate $\mathrm{BrO}$ levels ( $\sim 40-50 \mathrm{pmol} \mathrm{mol}^{-1}$; JD 201), oxidation of GEM under typical polar temperatures was more efficient than for the Dead Sea summer by $69.9 \%$ on average, and by $10.1 \%$ between typical Dead Sea winter and summer temperatures. Figure $7 \mathrm{a}$ shows that temperature effects were lower under high $\mathrm{BrO}_{\mathrm{x}}$ levels (JD 188), where differences in GEM depletions averaged $19.7 \%$ between Dead Sea summer and polar 
temperatures and $10.9 \%$ between typical Dead Sea winter and summer temperatures. We attribute these differences to the fact that GEM depletion becomes highly limited by low GEM concentrations in the presence of high $\mathrm{BrO}_{\mathrm{x}}$ concentrations.

Obrist et al. (2011) showed that RGM formation by $\mathrm{BrO}_{\mathrm{x}}$ at the Dead Sea occurred even at low BrO concentrations between $\sim 4$ and $6 \mathrm{pmol} \mathrm{mol}^{-1}$ (and possibly below because lower $\mathrm{BrO}$ could not be measured due to the DOAS detection limits), suggesting that $\mathrm{BrO}_{\mathrm{x}}$ has important implications for GEM depletions above oceans in the mid-latitudes and tropics. The present analysis indicates that GEM depletions in such areas may not be subject to strong temperature dependencies; at low $\mathrm{BrO}_{\mathrm{x}}$ levels (e.g., $\mathrm{BrO}<\sim 6.5 \mathrm{pmol} \mathrm{mol}^{-1}$, Saiz Lopez et al., 2004), [Br]/[BrO] ratios are expected to be significantly lower than $\sim 0.2-0.5$ (e.g., Fig. 5 ; Wayne et al., 1995), and thus BrO may be a dominant GEM oxidant if our proposed rate constants are confirmed for these areas.

\section{Summary and conclusions}

This study demonstrates that best agreement between model simulations and observed AMDEs at the Dead Sea was obtained by using $k_{\mathrm{Hg}+\mathrm{Br}}$ and $k_{\mathrm{Hg}+\mathrm{BrO}}$ of $2.7 \times 10^{-13}$ and $1.5 \times 10^{-13} \mathrm{~cm}^{3}$ molecule ${ }^{-1} \mathrm{~s}^{-1}$, respectively ("BASE" kinetics). A value $k_{\mathrm{Hg}+\mathrm{BrO}}$ of $5.0 \times 10^{-14} \mathrm{~cm}^{3}$ molecule $^{-1} \mathrm{~s}^{-1}$ is suggested as a minimum value. The "BASE" kinetics suggests a high efficiency and central role of $\mathrm{BrO}_{\mathrm{x}}$ with daytime relative contribution of more than $\sim 90 \%$ for AMDEs at the Dead Sea, with $\mathrm{BrO}$ being the dominant oxidant with relative contributions above $\sim 80 \%$. Using the "BASE" kinetics, $\mathrm{BrO}$ was found to be the dominant GEM oxidant for $[\mathrm{Br}] /[\mathrm{BrO}]$ ratios below $\sim 0.2-0.5$, which is usually the case in the troposphere. It should be emphasized that these rate constants are based on best agreements of observations and model results during AMDEs under Dead Sea conditions, and kinetic studies are necessary in order to confirm these suggested rate constants. High contributions of $\mathrm{BrO}$ to GEM oxidation suggests a low temperature dependency of GEM oxidation by $\mathrm{BrO}_{\mathrm{x}}$, indicating that $\mathrm{BrO}_{\mathrm{x}}$-induced GEM depletion can be important outside of the polar region even under relatively low $\mathrm{BrO}_{\mathrm{x}}$ levels.

\section{Supplementary material related to this article is available online at: http://www.atmos-chem-phys.net/12/2429/2012/ acp-12-2429-2012-supplement.pdf.}

Acknowledgements. We thank R. Sander for use of the MECCA model; the Dead Sea Works for site logistics; J. Zingler, J. Lenvant, and U. Corsmeier for meteorological data; Roger Kreidberg for editorial support to this manuscript; and reviewers and editors for suggestions that greatly improved this manuscript. The study was funded by the US National Science Foundation (no. 0813690 to
D. O. and M. L.) and has benefited from an US Environmental Protection Agency Star-to-Achieve grant (R833378).

Edited by: J. W. Bottenheim

\section{References}

Ariya, P., Dastoor, A., Amyot, M., Schroeder, W.H., Barrie, L., Anlauf, K., Raofie, F., Ryzhkov, A., Davignon, D., Lalonde, J., Steffen, A.: The Arctic: A sink for mercury, Tellus, 56B, 397403, 2004.

Ariya, P. A., Khalizov, A., and Gidas, A.: Reaction of gaseous mercury with atomic and molecular halogens: Kinetics, product studies, and atmospheric implications, J. Phys. Chem. A, 106, 7310-7320, 2002.

Ariya, P. A., Skov, H., Grage, M. M. L., and Goodsite, M. E.: Gaseous elemental mercury in the ambient atmosphere: Review of the application of theoretical calculations Calculated and experimental studies for determination of reaction coefficients and mechanisms with halogens and other reactants, Adv. Quantum. Chem., 55, 43-55, 2008.

Aspmo, K., Gauchard, P.-A., Steffen, A., Temme, C., Berg, T., Bahlmann, E., Banic, C., Dommergue, A., Ebinghaus, R., Ferrari, C., Pirrone, N., Sprovieri, F., and Wibetoe, G.: Measurements of atmospheric mercury species during an international study of mercury depletion events at Ny-Ålesund, Svalbard, spring 2003. How reproducible are our present methods? Atmos. Environ., 39, 7607-7619, 2005.

Berg, T., Sekkesæter, S., Steinnes, E., Valdal, A.-K., and Wibetoe, G.: Springtime depletion of mercury in the European Arctic as observed at Svalbard, Sci. Total Environ., 304, 43-51, 2003.

Bergan, T. and Rodhe, H.: Oxidation of elemental mercury in the atmosphere: Constraints imposed by global scale modeling, J. Atmos. Chem., 40, 191-212, 2001.

Bottenheim, J. W., Gallant, A. C., and Brice, K. A.: Measurements of $\mathrm{NO}_{\mathrm{y}}$ species and $\mathrm{O}_{3}$ at $82^{\circ} \mathrm{N}$ latitude, Geophys. Res. Lett., 13, 113-116, 1986.

Brooks, S., Saiz-Lopez, A., Skov, H., Lindberg, S., Plane, J. M. C., and Goodsite, M. E.: The mass balance of mercury in the springtime polar environment, Geophys. Res. Lett., 33, L13812, doi:10.1029/2005GL025525, 2006.

Byun, Y., Ko, K. B., Cho, M., Namkung, W., Koh, D. J., Lee, K., Hamilton, I. P., and Shin, D. N.: Insight into the Unique Oxidation Chemistry of Elemental Mercury by Chlorine-Containing Species: Experiment and Simulation, Environ. Sci. Technol., 44, 1624-1629, 2010.

Calvert, J. G. and Lindberg, S. E.: A modeling study of the mechanism of the halogen-ozone-mercury homogeneous reactions in the troposphere during the polar spring, Atmos. Environ., 37, 4467-4481, 2003.

Calvert, J. G. and Lindberg, S. E.: The potential influence of iodinecontaining compounds on the chemistry of the troposphere in the polar spring: II. Mercury depletion, Atmos. Environ., 38, 51055116, 2004.

Clever, H., Johnson, S. A., Derrick, E. M.: The solubility of mercury and some sparingly soluble mercury salts in water and aqueous solutions, J. Phys. Chem. Ref. Data., 14, 631-680, 1985.

Donohoue, D. L., Bauer, D., Cossairt, B., and Hynes, A. J.: Temperature and pressure dependent rate coefficients for the 
reaction of $\mathrm{Hg}$ with $\mathrm{Br}$ and the reaction of $\mathrm{Br}$ with $\mathrm{Br}$ : a pulsed laser photolysis-pulsed laser induced fluorescence study, J. Phys. Chem. A, 110, 6623-6632, 2006.

Driscoll, C. T., Han, Y. J., Chen, C. Y., Evers, D. C., Lambert, K. F., Holsen, T. M., Kamman, N. C., Munson, R. K.: Mercury contamination in forest and freshwater ecosystems in the northeastern United States, Bioscience, 57, 17-28, 2007.

Durnford, D. and Dastoor A.: The behavior of mercury in the cryosphere: A review of what we know from observations, J. Geophys. Res., 116, D06305, doi:10.1029/2010JD014809, 2011

Ebinghaus, R., Jennings, S. G., Schroeder, W., Berg, T., Donaghy, T., Guentzel, J., Kenny, C., Kock, H. H., Kvietkus, K., Landing, W., Mühleck, T., Munthe, J., Prestbo, E. M., Schneeberger, D. R., Slemr, F., Sommar, J., Urba, A., Wallschläger, D., and Xiao, Z.: International field inter-comparison measurements of atmospheric mercury species at Mace Head, Ireland, Atmos. Environ., 33, 3063-3073, 1999.

Ebinghaus, R., Kock, H. H., Temme, C., Einax, J. W., L“owe, A. G., Richter, A., Burrows, J. P., and Schroeder, W. H.: Antarctic springtime depletion of atmospheric mercury, Environ. Sci. Technol., 36, 1238-1244, 2002.

Evans, M. J., Jacob, D. J., Atlas, E., Cantrell, C. A., Eisele, F., Flocke, F., Fried, A., Mauldin, R. L., Ridley, B. A., Wert, B., Talbot, R., Blake, D., Heikes, B., Snow, J., Welega, J., Weinheimer, A. J., and Dibb, J.: Coupled evolution of $\mathrm{BrO}_{\mathrm{x}^{-}}$ ClOXHOX-NO $\mathrm{NO}_{\mathrm{x}}$ chemistry during bromine-catalyzed ozone depletion events in the Arctic boundary layer, J. Geophys. Res., 108, 8368, doi:10.1029/2002JD002732, 2003.

Gong, S. L., Barrie, L. A., and Blachey, J.-P.: Modelling sea-salt aerosols in the atmosphere. 1. Model development, J. Geophys. Res., 102, 3805, doi:10.1029/96JD02953, 1997.

Goodsite, M., Plane, J. M. C., and Skov, H.: A theoretical study of the oxidation of $\mathrm{Hg}^{0}$ to $\mathrm{HgBr}_{2}$ in the troposphere, Environ. Sci. Technol., 38, 1772-1776, 2004.

Hebestreit, K., Stutz, J., Rosen, D., Matveev, V., Peleg, M., Luria, M., and Platt, U.: First DOAS Measurements of Tropospheric Bromine Oxide in Mid Latitudes, Science, 283, 55-57, 1999.

Hedgecock, I. M. and Pirrone, N.: Mercury and photochemistry in the marine boundary layer-modelling studies suggest the in situ production of reactive gas phase mercury, Atmos. Environ., 35, 3055-3062, 2001.

Hedgecock, I. M. and Pirrone, N.: Chasing quicksilver: Modeling the atmospheric lifetime of $\mathrm{Hg} 0(\mathrm{~g})$ in the marine boundary layer at various latitudes, Environ. Sci. Technol., 38, 69-76, 2004.

Hedgecock, I. M., Pirrone, N., Sprovieri, F., and Pesenti, E.: Reactive gaseous mercury in the marine boundary layer: Modeling and experimental evidence of its formation in the Mediterranean region, Atmos. Environ., 37, S41-S49, 2003.

Hedgecock, I. M., Trunfio, G. A., Pirrone, N., and Sprovieri, F.: Mercury chemistry in the MBL: Mediterranean case and sensitivity studies using the AMCOTS (Atmospheric Mercury Chemistry over the Sea) model, Atmos. Environ., 39, 7217-7230, 2005.

Hedgecock, I. M., Pirrone, N., and Sprovieri, F.: Chasing quicksilver northward: Mercury chemistry in the Arctic troposphere, Environ. Chem., 5, 131-134, 2008.

Holmes, C. D., Jacob, D. J., and Yang, X.: Global lifetime of elemental mercury against oxidation by atomic bromine in the free troposphere, Geophys. Res. Lett., 33, L20808,
doi:10.1029/2006GL027176, 2006.

Holmes, C. D., Jacob, D. J., Mason, R. P., and Jaffe, D. A.: Sources and deposition of reactive gaseous mercury in the marine atmosphere, Atmos. Environ., 43, 2278-2285, 2009.

Karg, E., Uhl, J., and Heyder, J.: Particle Density of Sulfite and Sulfate Test Aerosols, J. Aerosol Sci., 26, Suppl. 1, S611-S612, 1995.

Kerkweg, A., Sander, R., Tost, H., Jöckel, P., and Lelieveld, J.: Technical Note: Simulation of detailed aerosol chemistry on the global scale using MECCA-AERO, Atmos. Chem. Phys., 7, 2973-2985, doi:10.5194/acp-7-2973-2007, 2007.

Kim, S. Y., Talbot, R., Mao, H., Blake, D. R., Huey, G., and Weinheimer, A. J.: Chemical transformations of $\mathrm{Hg}^{\circ}$ during Arctic mercury depletion events sampled from the NASA DC-8, Atmos. Chem. Phys. Discuss., 10, 10077-10112, doi:10.5194/acpd-1010077-2010, 2010.

Landgraf, J. and Crutzen, P. J.: An efficient method for online calculations of photolysis and heating rates, J. Atmos. Sci., 55, 863878, 1998.

Landis, M. S., Stevens, R. K., Schaedlich, F., and Prestbo, E. M.: Development and characterization of an annular denuder methodology for the measurement of divalent inorganic reactive gaseous mercury in ambient air, Environ. Sci. Technol., 36, 3000-3009, 2002.

Lin, C.-J. and Pehkonen, S. O.: Aqueous free radical chemistry of mercury in the presence of iron oxides and ambient aerosol, Atmos. Environ., 31, 4125-4137, 1997.

Lin, C.-J. and Pehkonen, S. O.: Oxidation of elemental mercury by aqueous chlorine ( $\mathrm{HOCl} / \mathrm{OCl}-)$ : Implications for tropospheric mercury chemistry, J. Geophys. Res., 103D, 28093-28102, 1998.

Lin, C.-J. and Pehkonen, S. O.: Aqueous phase reactions of mercury with free radicals and chlorine: Implications for atmospheric mercury chemistry, Chemosphere, 38, 1253-1263, 1999.

Lin, C.-J., Pongprueksa, P., Lindberg, S. E., Pehkonen, S. O., Byune, D., and Jang, C.: Scientific uncertainties in atmospheric mercury models I: Model science evaluation, Atmos. Environ., 40, 2911-2928, 2006.

Lindberg, S., Bullock, R., Ebinghaus, R., Engstrom, D., Feng, X., Fitzgerald, W., Pirrone, N., Prestbo, E., and Seigneur, Ch.: A synthesis of progress and uncertainties in attributing the sources of mercury in deposition, Ambio, 36, 19-32, 2007.

Lindberg, S. E., Brooks, S., Lin, C.-J., Scott, K., Meyers, T., Chambers, L., Landis, M., and Stevens, R. K.: Formation of Reactive Gaseous Mercury in the Arctic: Evidence of Oxidation of $\mathrm{Hg}^{\circ}$ to Gas-Phase Hg-II Compounds after Arctic Sunrise, Water Air Soil Pollut., 1, 295-302, 2001.

Lindberg, S. E., Brooks, S., Lin, C.-J., Scott, K. J., Landis, M. S., Stevens, R. K., Goodsite, M., and Richter, A.: Dynamic oxidation of gaseous mercury in the Arctic troposphere at polar sunrise, Environ. Sci. Technol., 36, 1245-1256, 2002.

Lu, J. Y., Schroeder, W. H., Barrie, L. A., and Steffen, A.: Magnification of atmospheric mercury deposition to polar regions in springtime: The link to tropospheric ozone depletion chemistry, Geophys. Res. Lett., 28, 3219-3222, 2001.

Mao, H., Talbot, R. W., Sigler, J. M., Sive, B. C., and Hegarty, J. D.: Seasonal and diurnal variations of $\mathrm{Hg}^{\circ}$ over New England, Atmos. Chem. Phys., 8, 1403-1421, doi:10.5194/acp-8-1403-2008, 2008.

Mao, H., Talbot, R., Sive, B., Kim, S. Y., Blake, D. R., and 
Weinheimer, A. J.: Arctic mercury depletion and its quantitative link with halogens, J. Atmos. Chem., 65, 145-170, 2010.

Matveev, V., Peleg, M., Rosen, D., Tov-Alper, D. S., Hebestreit, K., Stutz, J., Platt, U., Blake, D., and Luria, M.: Bromine oxideozone interactions over the Dead Sea, J. Geophys. Res, 106, 10375-10387, 2001.

McNider, R. T. and Pielke, R. A.: Diurnal boundary-layer development over sloping terrain, J. Atmos. Sci., 38, 2198-2212, 1981.

Munthe, J.: The aqueous oxidation of elemental mercury by ozone, Atmos. Environ. A-Gen., 26, 1461-1468, 1992.

Niki, H., Maker, P. D., Savage, C. M., and Breithnbach, L. P.: A long-path Fourier transform study of the kinetics and mechanism for the HO-radical initiated oxidation of dimethyl mercury, J. Phys. Chem, 87, 4978-4981, 1983.

Obrist, D., Tas, E., Peleg, M., Matveev, V., Faïn, X., Asaf, D., and Luria, M.: Bromine-induced oxidation of mercury in the midlatitude atmosphere, Nat. Geosci., 4, 22-26, 2011.

Pal, B. and Ariya, P. A.: Gas-phase HO-initiated reactions of elemental mercury: Kinetics, product studies, and atmospheric implications, Environ. Sci. Technol., 38, 5555-5566, 2004a.

Pal, B. and Ariya, P. A.: Studies of ozone initiated reactions of gaseous mercury: Kinetics, product studies, and atmospheric implications, Phys. Chem. Chem. Phys., 6, 572-579, 2004b.

Pehkonen, S. O. and Lin, C.-J.: Aqueous photochemistry of mercury with organic acids, J. Air. Waste. Manage., 48, 144-150, 1997.

Peleg, M., Matveev, V., Tas, E., and Luria, M.: Mercury Depletion Events in the Troposphere in Mid-Latitudes at the Dead Sea, Israel, Environ. Sci. Technol., 41, 7280-7285, 2007.

Petersen, G., Munthe, J., Pleijel, K., Bloxam, R., and Kumar, A. V.: A comprehensive Eulerian modeling framework for airborne mercury species: Development and testing of the tropospheric chemistry module (TCM), Atmos. Environ., 32, 829-843, 1998.

Pleijel, K. and Munthe, J.: Modelling the atmospheric mercury cycle - chemistry in fog droplet, Atmos. Environ., 29, 1441-1457, 1995.

Poissant, L. and Pilote, M.: Time series analysis of atmospheric mercury in Kuujjuarapik/Whapmagoostui (Qu'ebec), J. Phys. IV France, 107, 1079-1082, 2003.

Pszenny, A. A. P., Moldanová, J., Keene, W. C., Sander, R., Maben, J. R., Martinez, M., Crutzen, P. J., Perner, D., and Prinn, R. G.: Halogen cycling and aerosol $\mathrm{pH}$ in the Hawaiian marine boundary layer, Atmos. Chem. Phys., 4, 147-168, doi:10.5194/acp-4147-2004, 2004.

Raofie, F. and Ariya, P. A.: Kinetics and products study of the reaction of BrO radicals with gaseous mercury, J. Phys. IV France, 107, 1119-1121, 2003.

Raofie, F., Snider, G., and Ariya, P. A.: Departments of Chemistry and Atmospheric and Oceanic Sciences, McGill University, 801 Sherbrooke St. W., Montreal, QC H3A 2K6, Canada, 2008.

Saiz-Lopez, A., Plane, J. M. C., and Shillito, J. A.: Bromine oxide in the mid-latitude marine boundary layer, Geophys. Res. Lett., 31, L03111, doi:10.1029/2003GL018956, 2004.

Sander, R., Rudich, Y., von Glasow, R., and Crutzen., P. J.: The role of $\mathrm{BrNO}_{3}$ in marine tropospheric chemistry: A model study, Geophys. Res. Lett., 26, 2857-2860, 1999.

Sander, R., Kerkweg, A., Jöckel, P., and Lelieveld, J.: Technical note: The new comprehensive atmospheric chemistry module MECCA, Atmos. Chem. Phys., 5, 445-450, doi:10.5194/acp-5-
445-2005, 2005.

Sander, R., Burrows, J., and Kaleschke, L.: Carbonate precipitation in brine - a potential trigger for tropospheric ozone depletion events, Atmos. Chem. Phys., 6, 4653-4658, doi:10.5194/acp-64653-2006, 2006.

Schroeder, W. H. and Munthe, J.: Atmospheric mercury - An overview, Atmos. Environ., 32, 809-822, 1998.

Schroeder, W. H., Yarwood, G., and Niki, H.: Transformation processes involving mercury species in the atmosphere - Results from a literature survey, Water Air Soil Pollut., 56, 653-666, 1991.

Schroeder, W. H., Keeler, G., Kock, H., Roussel, P., Schneeberger, D., and Schaedlich, F.: International field inter-comparison of atmospheric mercury measurement methods, Water Air Soil Pollut., 80, 611-620, 1995.

Schroeder, W. H., Anlauf, K. G., Barrie, L. A., Lu, J. Y., Steffen, A., Schneeberger, D. R., and Berg, T.: Arctic springtime depletion of mercury, Nature, 394, 331-332, 1998.

Seigneur, C., Wrobel, J., Constantinou, E., Gillespie, P., Bergstrom, R. W., Sykes, I., Venkatram, A., and Karamchandani, P. A.: Chemical kinetic mechanism for atmospheric inorganic mercury, Environ. Sci. Technol., 28, 1589-1597, 1994.

Shepler, B. C., Balabanov, N. B., and Peterson, K. A.: $\mathrm{Hg}+\mathrm{Br} \rightarrow \mathrm{HgBr}$ recombination and collision-induced dissociation dynamics, J. Chem. Phys., 127, 164-304, doi:10.1063/1.2777142, 2007.

Shon, Z.-H., Kim, K.-H., Kim, M.-Y., and Lee, M.: Modeling study of reactive gaseous mercury in the urban air, Atmos. Environ., 39, 749-761, 2005.

Sillman, S., Marsik, F. J., Al-Wali, K. I., Keeler, G. J., and Landis, M. S.: Reactive mercury in the troposphere: Model formation and results for Florida, the northeastern United States, and the Atlantic ocean, J. Geophys. Res., 112, D23305, doi:10.1029/2006JD008227, 2007.

Skov, H., Christensen, J. H., Goodsite, M. E., Heidam, N. Z., Jensen, B., Wåhlin, P., and Geernaert, G.: Fate of elemental mercury in the Arctic during atmospheric mercury depletion episodes and the load of atmospheric mercury to the Arctic, Environ. Sci. Technol., 38, 2373-2382, 2004.

Smith, R. M. and Martell, A. E.: Critical stability constants Inorganic Complexes, vol. 4, Plenum, New York, 1976.

Smoydzin, L. and von Glasow, R.: Modelling chemistry over the Dead Sea: bromine and ozone chemistry, Atmos. Chem. Phys., 9, 5057-5072, doi:10.5194/acp-9-5057-2009, 2009.

Sommar, J., Hallquist, M., Ljungstrom E., and Lindqvist, O.: On the gas phase reactions between volatile biogenic mercury species and the nitrate radical, J. Atmos. Chem., 27, 233-247, 1997.

Sommar, J., Wängberg, I., Berg, T., Gårdfeldt, K., Munthe, J., Richter, A., Urba, A., Wittrock, F., and Schroeder, W. H.: Circumpolar transport and air-surface exchange of atmospheric mercury at $\mathrm{Ny}-$ Ålesund $\left(79^{\circ} \mathrm{N}\right)$, Svalbard, spring 2002, Atmos Chem. Phys., 7, 151-166, doi:10.5194/acp-7-151-2007, 2007.

Spicer, C. W., Satola, J., Abbgy, A. A., Plastridge, R. A., and Cowen, K. A.: Kinetics of gas-phase elemental mercury reactions with halogen species, ozone, and nitrate radical under atmospheric conditions: Tallahassee, FL, Florida Department of Environmental Protection, 1-20, 2002.

Spivakovsky, C. M., Logan, J. A., Montzka, S. A., Balkanski, Y. J., Foreman-Fowler, M., Jones, D. B. A., Horowitz, L.W., Fusco, A. 
C., Brenninkmeijer, C. A. M., Prather, M. J., Wofsy, S. C., and McElroy, M. B.: Three-dimensional climatological distribution of tropospheric OH: Update and evaluation, J. Geophys. Res., 105, 8931-8980, doi:10.1029/1999JD901006, 2000.

Steffen, A., Douglas, T., Amyot, M., Ariya, P., Aspmo, K., Berg, T., Bottenheim, J., Brooks, S., Cobbett, F., Dastoor, A., Dommergue, A., Ebinghaus, R., Ferrari, C., Gardfeldt, K., Goodsite, M. E., Lean, D., Poulain, A. J., Scherz, C., Skov, H., Sommar, J., and Temme, C.: A synthesis of atmospheric mercury depletion event chemistry in the atmosphere and snow, Atmos. Chem. Phys., 8, 1445-1482, doi:10.5194/acp-8-1445-2008, 2008.

Stephens, C., Shepson, P. B., Steffen, A., Bottenheim, J. W., Liao, J., Huey, L. G., Apel, E. C., Weinheimer, A. J. J., Hall, S. R., Cantrell, C. A., Sive, B. C., Knapp, D., Montzka, D., and Hornbrook, R. S.: The relative importance of Chlorine and Bromine radicals in the oxidation of atmospheric Mercury at Barrow, AK, J. Geophys. Res., doi:10.1029/2011JD016649, in press, 2012.

Stutz, J. and Platt, U.: Numerical analysis and estimation of the statistical error of differential optical absorption spectroscopy measurements with least-squares methods, Appl. Optics, 35, 60416053, 1996.

Subir, M., Ariya, P. A., and Dastoor, A. P.: A review of uncertainties in atmospheric modeling of mercury chemistry I. Uncertainties in existing kinetic parameters - Fundamental limitations and the importance of heterogeneous chemistry, Atmos. Environ., 45, 5664-5676, 2011.

Tas, E., Peleg, M., Matveev, V., Zingler, J., and Luria, M.: Frequency and extent of bromine oxide formation over the Dead Sea, J. Geophys. Res., 110, D11304, doi:10.1029/2004JD005665, 2005.

Tas, E., Peleg, M., Pedersen, D. U., Matveev, V., Pour Biazar, A., and Luria, M.: Measurement-based modeling of bromine chemistry in the boundary layer: 1 . Bromine chemistry at the Dead Sea, Atmos. Chem. Phys., 6, 5589-5604, doi:10.5194/acp-65589-2006, 2006.

Tas, E., Peleg, M., Pedersen, D. U., Matveev, V., Biazar, A. P., and Luria, M.: Measurement-based modeling of bromine chemistry in the Dead Sea boundary layer - Part 2: The influence of $\mathrm{NO}_{2}$ on bromine chemistry at mid-latitude areas, Atmos. Chem. Phys., 8, 4811-4821, doi:10.5194/acp-8-4811-2008, 2008.

Tokos, J. J. S., Hall, B., Calhoun, J. A., and Prestbo, E. M.: Homogeneous gas-phase reaction of $\mathrm{Hg}^{0}$ with $\mathrm{H}_{2} \mathrm{O}_{2}, \mathrm{O}_{3}, \mathrm{CH}_{3} \mathrm{I}$, and $\left(\mathrm{CH}_{3}\right)_{2} \mathrm{~S}$ : Implications for atmospheric $\mathrm{Hg}$ cycling, Atmos. Environ., 32, 823-827, 1998.
Tossell, J. A.: Calculation of the energetics for oxidation of gasphase elemental $\mathrm{Hg}$ by $\mathrm{Br}$ and $\mathrm{BrO}$, Phys. Chem. A, 107, 78047808, 2003.

Tossell, J. A.: Calculation of the energetics for the oligomerization of gas phase $\mathrm{HgO}$ and $\mathrm{HgS}$ and for the solvolysis of crystalline $\mathrm{HgO}$ and $\mathrm{HgS}$, J. Phys. Chem. A, 110, 2571-2578, 2006.

Van Loon, L., Mader, E., and Scott, S. L.: Reduction of the aqueous mercuric ion by sulfite: UV spectrum of $\mathrm{HgSO}_{3}$ and its intramolecular redox reaction, J. Phys. Chem. A, 104, 1621-1626, 2000.

Van Loon, L. L., Mader, E. A., and Scott, S. L.: Sulfite stabilization and reduction of the aqueous mercuric ion: Kinetic determination of sequential formation constants, Phys. Chem. A, 105, 3190-3195, 2001.

Vogt, R., Crutzen, P. J., and Sander, R.: A mechanism for halogen release from sea- salt aerosol in the remote marine boundary layer, Nature, 383, 327-330, 1996.

Wang, Z. and Pehkonen, S. O.: Oxidation of elemental mercury by aqueous bromine: Atmospheric implications, Atmos. Environ., 38, 3675-3688, 2004.

Wayne, R. P., Poulet, G., Biggs, P., Burrows, J. P., Cox, R. A., Crutzen, P. J., Haymann, G. D., Jenkin, M. E., Bras, G. L., Moortgat, G. K., Platt, U., and Schindler, R. N.: Halogen oxides: Radicals, sources and reservoirs in the laboratory and in the atmosphere, Atmos. Environ., 29, 2675-2884, 1995.

Xiao, Z. F., Munthe, J., Stromberg, D., and Lindqvist, O.: Photochemical behavior of inorganic mercury compounds in aqueous solution, in: Mercury as a Global Pollutant - Integration and Synthesis, edited by: Watras, C. J. and Huckabee, J. W., Lewis Publishers, 581-592, 1994.

Xie, Z.-Q., Sander, R., Pöschl, U., and Slemr, F.: Simulation of atmospheric mercury depletion events (AMDEs) during polar springtime using the MECCA box model, Atmos. Chem. Phys., 8, 7165-7180, doi:10.5194/acp-8-7165-2008, 2008.

Yue, G. K.: On the Characteristics of Sulfate Aerosols formed in the Presence of Ion Sources, J. Aerosol Sci., 10, 387-393, 1979.

Zingler, J. and Platt, U.: Iodine oxide in the Dead Sea Valley: Evidence for inorganic sources of boundary layer IO, J. Geophys. Res., 110, D07307, doi:10.1029/2004JD004993, 2005. 